\title{
A Review on the Effect of Rooting Media on Rooting and Growth of Cutting Propagated Grape (Vitis vinifera $L$ )
}

\author{
Abera Jaleta* and Mahbuba Sulaiman \\ Department of Horticulture, Bedele College of Agriculture and Forestry, Mettu University, Ethiopia
}

*Corresponding author: Abera Jaleta, Department of Horticulture, Bedele College of Agriculture and Forestry, Mettu University, Ethiopia.

Received Date: October 18, 2019

Published Date: October 29, 2019

\begin{abstract}
The objective of the current review is to review and identify the research gap on the effect of different growth media on rooting percentage, roots and shoot growth performance of grape cutting. Factors affecting rooting of grape cuttings can be internal or external factors. Internal factors affecting rooting of cuttings include the amount of stored food in cuttings, the age and maturity of tissue, the formation of callus and adventitious roots and the presence of leaves and buds on cuttings. The external factors include rooting media, chemical and hormone treatments, light, temperature, mechanical treatment and mist spray. Rooting media is one of the most important factors for rooted cutting production especially in grape. It is one of the factors affecting rooting and growth of grape cuttings. Types of media have significantly influenced the rooting and vegetative growth of cuttings. Different planting media have significantly influenced the vegetative growth of cuttings; due to the level of organic matter content, water holding difference. The suitability of the rooting medium depends on the species, type of cuttings, growing conditions, season of the year and the cost effectiveness of the medium components. A media which is light, rich, porous, well drained and free from pathogens is considered ideal for growing of grape. A good potting medium must be easy to supply, process and a cheap source. Choosing the most suitable growing media for the achievement of a successful plant production is very important.
\end{abstract}

Keywords: Rooting media; Grape; Growth; Cutting; Rooting; Rooting substrates

\section{Introduction}

Grape (Vitis vinifera L.) is one of the important commercial subtropical vine crops grown all over the world except at a few places with high altitude and extreme temperature [1]. It is native to the Mediterranean region, central Europe, and southwestern Asia, from Morocco and Portugal north to southern Germany and east to northern Iran. It belongs to the family Vitaceae, is one of the oldest, most extensively cultivated and economically significant fruit crops in the world [2,3].

The three major uses of grapes are; wine making, fresh fruit (table grapes) and dried fruit (raisins) production. It can be used for making wine, jam, juice, jelly, grape seed extract, ethanol, raisins, vinegar, grape seed oil, tartaric acid, fertilizer, grape derived antioxidant compounds (polyphenols, resveratrol) and etc. Grape also associated with prevention of cancer, heart disease, high blood pressure, allergies, diabetes, constipation etc. [4].

It is a vine crop and trained on wires on both sides of plant. It is a short duration crop and consumed as fresh and in dried form [5].
Global grape production currently amounts to more than 75 million metric tons per year. Today there are over 18 million acres of cultivated vineyards worldwide. The top 5 grape producing counties are China, Italy, United States, France and Spain respectively, while Ethiopia is 77 th in the world.

In Ethiopia, the total grape production, harvested area and yield of grape in the year 2014 was reached 5118 tones, 2544 ha and 20123 hectogram ha ${ }^{-1}$, respectively [6].

Grape propagation for commercial vineyards includes the use of cuttings, rooting, budding, layers and grafts [7]. Cutting is one of the extensively practiced means of vegetative propagation of plants in horticulture industry [8] and is the most important practices in viticulture [9]. It has many advantages such as being economical [1], require a limited space, simple [8,10], rapid for dissemination of selected clones or new varieties resulting from breeding programs $[8,11]$. It maintains true to type varietal characteristics $[7,12,13]$. Cutting is highly practical and economically important. It is used 
extensively to propagate ornamental plants, including deciduous types, broad-leaved evergreens and coniferous forms. Fruits such as grapes and figs have been propagated in this manner since ancient times [14].

Grapevines are very easy to grow from cuttings $[8,13]$. It is well known that in comparison to soft wood cuttings, grapes are generally propagated through hardwood cuttings [8]. The main reasons are due to its highest success rate $[9,15]$ without the use of special rooting technique, least expensive and easiest method of vegetative propagation $[12,13,16]$. Cuttings can also be made from the stem, modified stem, roots or leaves [13].

Rooting media is one of the most important factors for rooted cutting production. It is one of the factors affecting rooting and growth of grape cuttings [4]. Types of media have significantly influenced the rooting and vegetative growth of cuttings. Growing media should be considered an essential part of the propagation system because rooting competency depends on the type of medium used. Rooting medium directly effect on quality and percentage of rooting [5]. Both the biological and physico-chemical characteristics of a potting medium affect plant and root growth [4]. It is known that good growth media provides a reservoir for plant nutrients, hold plant available water, and provide a means for gas exchange and good anchorage for the plants [17].

\section{Objectives}

- To review the effect of different growth media on rooting percentage, roots and shoot growth performance of grape cutting.

- To identify research gap on the effect of growth media on rooting and required growth performance of grape cutting.

\section{Review on the Effect of Media on Rooting and Growth of Cuttings of Grape}

The quality of potting mixes and field nursery soils is critical to cutting establishment [13]. It is known that good growth media provides a reservoir for plant nutrients, hold plant available water, and provide a means for gas exchange and good anchorage for the plants [17-19]. Lack of one or more of these beneficial characteristics leads to lower rooting percentage of cuttings or undesirable root shape and or form [18]. Thus, growers typically use peat, perlite, vermiculite, sand, fallow land and organic and inorganic composted materials to prepare nutritious potting mixtures [20].

\section{Review on the effect of media on rooting and root growth parameters of grape cutting}

Effect of media on rooting percentage of grape cutting: Factors affecting rooting of grape cuttings can be internal or external factors. Internal factors affecting rooting of cuttings include the amount of stored food in cuttings, the age and maturity of tissue, the formation of callus and adventitious roots and the presence of leaves and buds on cuttings. The external factors include rooting media, chemical and hormone treatments, light, temperature, mechanical treatment and mist spray [14].
Many papers present studies on the effect of various media for rooting cuttings. Vermiculite, perlite, and other products have been and are being tested with a view of improving plant propagation methods [14].

Many mixtures have been used as media for propagation. Cuttings of some plants which root poorly in sand, often root satisfactorily in mixtures of equal volumes of sand and peat. A mixture of equal parts of peat and sawdust was satisfactory for rooting of grape. A mixture which contained 1 part of peat, 1 part of sand, and 1 part of sawdust also proved satisfactory [21]. Any medium which holds moisture and supplies air is satisfactory. However, different media cause variations in root quality [22]. Of 43 kinds of plants propagated by stem cuttings, 30 produced finer and more flexible roots in peat moss than in sand due to the reduced aeration and increased moisture [14].

When cuttings are rooted in sand and peat moss or perlite and peat moss, the roots developed are well branched, slender and flexible, a type much more suited for digging and repotting [23]. Among some of the rooting media used in Ghana is a mixture of equal parts of coarse river sand and composted oil palm fiber. The fiber holds moisture while the sand keeps the mixture open and well aerated [24].

Tsipouridis et al. [25] studied on five rooting substrates (perlite (1-5 mm), peat, perlite + peat (50:50\%), sand and perlite (covered cuttings were additionally enclosed in a polyethylene bag)) and found rooting the 50:50 peats perlite mixtures gave a reasonable amount.

Dvin et al. [18] also reported that using of coco peat + perlite media resulted in higher percentage of cuttings that rooted.

Ibrahim [24], showed that sand/ fiber mixture gave a higher percentage of rooting success and produced stronger and more fibrous roots than sand, fiber or peat moss alone.

Muhammad et al. [5] observed that the statistical analysis depicts significance of potting media on the rooting percentage $(\mathrm{P}<0.05)$. CSb and CSBCP potting media had more than $70 \%$ rooting in comparison to CS and CSFYM potting media with less than $50 \%$. The highest mean rooting percentage (84.44) was observed from grape cuttings grown in potting media having mixture of canal silt (25\%), bagasse (50\%) and coco peat (25\%).

Research done by Krishna [1] as in (Table 1) better rooting obtained from sand +10 or $20 \%$ coco peat for hardwood cuttings of both Dogridge and 1613C. While in case of soft wood cuttings, sand $+10 \%$ coco peat recorded significantly higher percentage of rooting in both varieties (Table 1).

Ferrer et al. [26] reported that, percentage rooting was highest in sand (84.9), followed by soil (37.7) and the soil + sand mix (27.8). But the root development in sand was poor and the plants were not commercially acceptable. While the cuttings rooted in soil + sand mix produced better root and shoot development. 
Table 1: Effect of different proportions of sand and coco peat on percentage of rooting in hardwood cuttings of grape.

\begin{tabular}{|c|c|c|c|c|c|c|}
\hline Rooting Media & Sand & Sand + 10\% Cocopeat & Sand + 20\% Cocopeat & Sand + 30\% Cocopeat & Mean \\
\hline Varieties & \multicolumn{5}{|c|}{} & \\
\hline Dogridge & $73.33(58.98)$ & $86.67(68.83)$ & $90.00(71.54)$ & $70.00(56.77)$ & $80.00(64.02)$ \\
\hline $1613 \mathrm{C}$ & $70.00(56.97)$ & $80.00(63.90)$ & $76.67(61.19)$ & $73.33(59.79)$ & $75.00(60.31)$ \\
\hline Mean & $71.67(57.98)$ & $83.33(66.37)$ & $83.33(66.37)$ & $71.67(57.98)$ & \\
\hline
\end{tabular}

Source: Kishan [21].

Source of variation

CD (0.05)

Varieties

NS

Rooting Media

6.17

Varieties x Rooting media

NS

*Figures in Parenthesis are angular transformed values.

NS - Not Significant

Kawecki \& Kozlowski [27] studied the effect of nine different organic substrates viz., municipal waste compost, conifer bark, peat, sand, fresh or old conifer sawdust, and hardwood sawdust in different combinations on rooting of one-bud hardwood cuttings of grape cv. Skarb Panoii. They found best rooting after five weeks on a substrate containing 8-year-old sawdust + sand or sand mixed with lowland peat.

Cyrillo et al. [28] observed no difference between two rooting media viz., vermiculite and washed river sand when used for rooting of semi hardwood cuttings of the grape rootstocks, 'IAC 313 Tropical' and 'IAC 766 Campinas' in a mist chamber.

Song et al. [29] observed sand + vermiculite as best basic substrate for rooting of cuttings in four grape varieties derived from crosses involving Vitis amuriensis.

Haile [4] Cutting rooted in agricultural soil + sand (75:25 v/v) gave the highest percent of cuttings that rooted (85.96\%), however, statistical difference was not observed between agricultural soil (100\%) and coco peat (100\%) media. Similar result was reported by Sabir et al. [19], Dvin et al. [18], Sengel et al. [30] and Galavi et al. [17] in that rooting percentage of cuttings was significantly affected by the type of rooting media used.

Effect of media on number of roots per cutting: Muhammad et al. [5] done research using four media mixtures a. CS - canal silt (100\%), b. CSFYM - canal silt (75\%) + FYM (25\%), c. CSB - canal silt $(25 \%)+$ bagasse $(75 \%)$ and $d$. CSBCP - canal silt $(25 \%)+$ bagasse $(50 \%)+$ coco peat $(25 \%)(w / w)$ and the statistical analysis reveals that number of roots per cutting was significantly affected by the potting media and the higher mean numbers of roots (50.00) were obtained in CSBCP potting medium.

Research done by [1] using 4 treatments T1 Sand T2 : Sand + $10 \%$ coco peat T3: Sand $+20 \%$ coco peat T 4 : Sand $+30 \%$ coco peat with two types of cutting (semi hard and hard wood cutting) and 2 varieties indicated the number of roots per cutting recorded were greater in sand $+20 \%$ coco peat.

Singh \& Nair [11] reported the effect of rooting media on root formation in cuttings of ornamental plants, planted in red soil, sand and compost in the ratio of 1:2:1, 1:1:2 and 2:1:1. Maximum root number was observed in media red soil + sand + compost (1:1:1).

As the observation of Gebreslassie [31] the largest number of roots per cutting (18) was recorded under rooting media composition of 6TS:3FYM :2FS.

In Rashad et al. [32] experiment different growing media such as Peat moss: Sand: Sawdust (1:1:1), Silt, Top soil and Bagasse: Silt (1:1) and different cutting height (Bottom, Middle and Top) were evaluated by using single concentration of IBA (400 $\mathrm{mg} \mathrm{kg}^{-1}$ ) on guava. Results indicated that silt media had recorded significantly higher number of roots $(28.78 \pm 3.99)$.

Effect of media on fresh weight of roots cutting: The study of Muhammad et al. [5] indicated that fresh weight of roots per cutting was significantly affected by the potting media. Results depicts that the highest fresh weight of roots per cuttings (2.16) was observed from the cuttings planted in CSB potting medium having mixture of canal silt (25\%) and bagasse (75\%). They further concluded that combination of canal silt (25\%) and bagasse (75\%) (CSB potting medium) as well as CSBCP [canal silt (25\%) + bagasse (50\%) and coco peat $(25 \%)$ potting medium] had produced best results for sprouting and growth of grape seedlings.

In Haile's (2017) study, root fresh weight was significantly $(\mathrm{P} \leq 0.01)$ influenced by rooting media. Stem cuttings rooted in agricultural soil + sand (75:25 v/v) gave significantly (Table 2) heavier $(15.30 \mathrm{~g})$ fresh root mass, while the minimum root mass (12.45g) was found in those cuttings rooted in agricultural soil (100\%), which however was not statistically different from those cuttings rooted in filter cake + sand $(50: 50 \mathrm{v} / \mathrm{v})$ and coco peat (100\%). Galavi et al., [17] also noted that root fresh weight of grape rooted cuttings was higher in agricultural soil + sand planting bed than pure sandy bed and agricultural soil beds.

Shah et al. [33] also reported significant effects of rooting media on root fresh weight of rooted cuttings.

In an experiment, Hong et al. [34] used different media mixtures viz., 100 per cent vermiculite, 100 per cent granulated cotton, 70 per cent vermiculite +30 per cent perlite, 70 per cent vermiculite +30 per cent peat moss and 50 per cent vermiculite +50 per cent perlite for the acclimatization of in vitro cultured grape cv. Rizamat 
plantlets and found that 100 per cent granulated cotton followed by 70 per cent vermiculite +30 per cent peat moss were best. The root weight was best in 70 per cent vermiculite +30 per cent peat moss.

Gebresilassie [31] report shows that the highest fresh weight $(30 \mathrm{~g})$ was recorded from hard wood cutting type grown in media composed of l/3rd SS top + 2TS:1FYM :1FS.

Table 2: Root growth parameters of grape cuttings as affected by rooting media and variety.

\begin{tabular}{|c|c|c|c|c|c|c|c|}
\hline \multirow[b]{2}{*}{ Treatments } & \multicolumn{7}{|c|}{ Root Growth Parameters } \\
\hline & $\begin{array}{c}\text { Rooting Percentage } \\
(\%)\end{array}$ & $\begin{array}{l}\text { Root Length } \\
\text { (cm) }\end{array}$ & $\begin{array}{l}\text { Root Number } \\
\text { Cutting }^{-1}\end{array}$ & $\begin{array}{l}\text { Root Fresh } \\
\text { Wt. (g) }\end{array}$ & $\begin{array}{l}\text { Root Dry } \\
\text { Wt. (g) }\end{array}$ & R:S Ratio & $\begin{array}{c}\text { Rooting Index } \\
(\%)\end{array}$ \\
\hline \multicolumn{8}{|c|}{ Variety (VAR) } \\
\hline Greenish Noir & $78.12^{\mathrm{b}}$ & 27.49 & $37.21^{\mathrm{b}}$ & $13.23^{\mathrm{b}}$ & $2.13^{\mathrm{b}}$ & $0.62^{\mathrm{a}}$ & $14.38^{\mathrm{b}}$ \\
\hline Sangiovese & $77.01^{\mathrm{b}}$ & 26.19 & $41.85^{b}$ & $10.62^{c}$ & $2.86^{\mathrm{a}}$ & $0.55^{\mathrm{b}}$ & $15.18^{\mathrm{b}}$ \\
\hline Cannonau & $87.92^{\mathrm{a}}$ & 28.41 & $67.38^{\mathrm{a}}$ & $15.51^{\mathrm{a}}$ & $2.13^{\mathrm{b}}$ & $0.50^{\mathrm{b}}$ & $19.02^{\mathrm{a}}$ \\
\hline $\mathrm{LSD}_{0.05}$ & 2.87 & ns & 5.01 & 1.72 & 0.16 & 0.07 & 1.94 \\
\hline \multicolumn{8}{|c|}{ Rooting Media (MED) } \\
\hline Agricultural Soil (100\%) & $77.64^{\mathrm{c}}$ & $28.76^{\mathrm{a}}$ & $33.44^{\mathrm{c}}$ & $12.45^{\mathrm{b}}$ & $2.55^{\mathrm{b}}$ & $0.38^{c}$ & $12.07^{\mathrm{c}}$ \\
\hline Agri. Soil + Sand (75:25v/v) & $85.96^{\mathrm{a}}$ & $29.72^{\mathrm{a}}$ & $54.86^{\mathrm{b}}$ & $15.30^{\mathrm{a}}$ & $3.50^{\mathrm{a}}$ & $0.79^{\mathrm{a}}$ & $21.07^{\mathrm{a}}$ \\
\hline Filter Cake + Sand $(50: 50 v / v)$ & $82.36^{\mathrm{b}}$ & $29.49^{a}$ & $33.36^{c}$ & $12.08^{\mathrm{b}}$ & $2.69^{\mathrm{b}}$ & $0.54^{\mathrm{b}}$ & $14.09^{c}$ \\
\hline Coco Peat $(100 \%)$ & $78.1^{\mathrm{c}}$ & $21.50^{\mathrm{b}}$ & $69.58^{\mathrm{a}}$ & $12.64^{\mathrm{b}}$ & $0.77^{\mathrm{c}}$ & $0.52^{\mathrm{b}}$ & $17.54^{\mathrm{b}}$ \\
\hline $\mathrm{LSD}_{0.05}$ & 3.32 & 3.19 & 5.79 & 1.98 & 0.18 & 0.08 & 2.24 \\
\hline CV (\%) & 4.21 & 11.98 & 12.44 & 15.52 & 8.01 & 14.24 & 14.23 \\
\hline VAR * MED & $* *$ & $*$ & $* * *$ & ns & $* *$ & $* *$ & $* *$ \\
\hline
\end{tabular}

Source: Haile [16].

- Column means with the same letter are not significantly different at $\mathrm{P}<0.05$ probability level, ns: Non-Significant, ${ }^{*}=\mathrm{P} \leq 0.05,{ }^{* *}=\mathrm{P} \leq 0.01$, Agri. Soil $=$ Agricultural Soil, R:S = root to shoot ratio, Wt. = Weight

Dvin et al. [18], also found that significantly longer roots on apple hardwood cuttings (MM111) rooted in coco peat + perlite medium. However, Sengel et al. [50] reported non-significant effect of rooting media on root length.

Hong et al. [34] used different media mixtures viz., 100 per cent vermiculite, 100 per cent granulated cotton, 70 per cent vermiculite +30 per cent perlite, 70 per cent vermiculite +30 per cent peat moss and 50 per cent vermiculite +50 per cent and He found root length was highest in 100 per cent granulated cotton.

Research done by [1] using 4 treatments T1 Sand T2 : Sand + $10 \%$ coco peat T3 : Sand $+20 \%$ coco peat T 4 : Sand $+30 \%$ coco peat with two types of cutting (semi hard and hard wood cutting) and 2 varieties indicated them maximum length of longest root was recorded in sand $+30 \%$ coco peat in both hardwood and semi hard wood cuttings.

In Rashad's et al. [32] experiment (Peat moss: Sand: Sawdust (1:1:1), Silt, Top soil and Bagasse: Silt (1:1) and different cutting height (Bottom, Middle and Top)) with single concentration of IBA ( $400 \mathrm{mg} \mathrm{kg}^{-1}$ ) on guava, Silt media had recorded significantly higher root length $(24.95 \pm 5.00 \mathrm{~cm})$.

\section{Effect of media on growth of grape}

The growth and survival of the grape seedlings in a nursery is greatly affected by the potting medium. As it is a key source of nutrition and provides root system to the plants. Besides, water
Effect of media on root length per cutting of grape: Singh and Nair [11] reported that the longest root length was observed in media red soil + sand + compost $(1: 1: 1)$.

Haile [4] recommended agricultural soil + sand (75:25 v/v) out of the 4 rooting media i.e. agricultural soil (100\%), agricultural soil+ sand $(75: 25 \mathrm{v} / \mathrm{v})$, filter cake + sand $(50: 50 \mathrm{v} / \mathrm{v})$ used for longest $(29.72 \mathrm{~cm}$ ) root length (Table 2 ).

Root Growth Parameters

Rumber $\quad$ Root Fresh

(VAR)

holding capacity, better aeration, root penetration, presence of organic matter in the growing medium and so many other related factors are greatly influenced by the growing medium. A good potting medium must be easy to supply, process and a cheap source [35].

Different planting media have significantly influenced the vegetative growth of cuttings; due to the level of organic matter content, water holding difference [19]. The level of nitrogen and potassium in rooting media also plays a vital role in vegetative growth of the plant and improving the water utilization capacity of plant, respectively [30].

Effect of media on number of leaves per cutting of grape: stem cutting (17.00) from the stem cuttings planted in the potting medium had mixture of canal silt $(25 \%)$ and bagasse $(75 \%)$. Statistically similar results were also observed from the cuttings grown in the medium contained canal silt, bagasse and coco peat at 25,50 and $25 \%$ respectively.

Haile [4] indicated that stem cutting rooted in filter cake + sand $(50: 50 \mathrm{v} / \mathrm{v})$ gave on average of 21.42 leaves plant ${ }^{-1}$, which however was not statistically different from those cuttings rooted in agricultural soil + sand (75:25v/v) (Table 3). Shah et al. [33] and Popescu \& Popescu [20] also described that the significant effect of rooting media on number of leaves plant ${ }^{-1}$. Muhammad et al. [5] observed maximum number of leaves per 
Table 3: Effects of potting media and grape variety on growth indices of grape cuttings.

\begin{tabular}{|c|c|c|c|c|c|c|}
\hline \multirow{2}{*}{ Growth Index } & \multirow{2}{*}{ Grape Varieties } & \multicolumn{4}{|c|}{ Potting Media (M) } & \multirow{2}{*}{ Mean } \\
\hline & & CS & CSFYM & CSB & CSBCP & \\
\hline \multirow{4}{*}{ Days to Sprouting (Days) } & Red Globe & $12.67^{\mathrm{a}}$ & $16.00^{\mathrm{a}}$ & $8.33^{\mathrm{de}}$ & $8.00^{\mathrm{et}}$ & $11.25^{\mathrm{A}}$ \\
\hline & Thompson Seedless & $10.33^{c}$ & $12.00^{\mathrm{b}}$ & $6.67^{\mathrm{fg}}$ & $6.00^{\mathrm{g}}$ & $8.75^{c}$ \\
\hline & Crimson Seedless & $9.67^{\mathrm{cd}}$ & $16.67^{\mathrm{a}}$ & $6.33^{\mathrm{g}}$ & $6.33^{\mathrm{g}}$ & $9.75^{\mathrm{B}}$ \\
\hline & Mean & $10.89^{\mathrm{B}}$ & $14.89^{\mathrm{A}}$ & $7.11^{\mathrm{C}}$ & $6.78^{\mathrm{C}}$ & \\
\hline \multirow{4}{*}{ Sprouting Percentage Treatment ${ }^{-1}(\%)$} & Red Globe & $46.66^{\mathrm{a}}$ & $16.66^{\mathrm{a}}$ & $70.00^{\mathrm{bc}}$ & $76.66^{\mathrm{bc}}$ & $52.50^{c}$ \\
\hline & Thompson Seedless & $40.00^{\mathrm{ab}}$ & $23.33^{\text {av }}$ & $90.00^{\mathrm{a}}$ & $83.33^{\mathrm{b}}$ & $59.17^{\mathrm{A}}$ \\
\hline & Crimson Seedless & $40.00^{\mathrm{ab}}$ & $16.67^{\mathrm{a}}$ & $73.33^{\mathrm{b}}$ & $93.33^{\mathrm{a}}$ & $55.83^{\mathrm{B}}$ \\
\hline & Mean & $42.22^{\mathrm{B}}$ & $18.89^{\mathrm{C}}$ & $77.78^{\mathrm{A}}$ & $84.44^{\mathrm{A}}$ & \\
\hline \multirow{4}{*}{ No. of Sprouts Cutting ${ }^{-1}$} & Red Globe & $3.33^{\mathrm{a}}$ & $1.66^{\mathrm{b}}$ & $6.00^{\mathrm{a}}$ & $4.66^{\mathrm{bc}}$ & $3.91^{\mathrm{A}}$ \\
\hline & Thompson Seedless & $3.00^{\mathrm{bc}}$ & $1.66^{\mathrm{b}}$ & $5.00 \mathrm{~b}^{\mathrm{c}}$ & $5.33^{\mathrm{a}}$ & $3.75^{\mathrm{A}}$ \\
\hline & Crimson Seedless & $3.33^{\mathrm{a}}$ & $1.33^{\mathrm{a}}$ & $5.66^{\mathrm{ab}}$ & $5.00^{\mathrm{ab}}$ & $3.83^{\mathrm{a}}$ \\
\hline & Mean & $3.22^{\mathrm{B}}$ & $1.55^{\mathrm{C}}$ & $5.55^{\mathrm{A}}$ & $5.00^{\mathrm{A}}$ & \\
\hline \multirow{4}{*}{ Morality Percentage (\%) } & Red Globe & $3.933^{\mathrm{C}}$ & $10.94^{\mathrm{A}}$ & $0.00^{\mathrm{D}}$ & $0.00^{\mathrm{D}}$ & $3.72^{\mathrm{A}}$ \\
\hline & Thompson Seedless & $5.13^{\mathrm{c}}$ & $8.26^{\mathrm{B}}$ & $0.00^{\mathrm{D}}$ & $0.00^{\mathrm{D}}$ & $3.35^{\mathrm{AB}}$ \\
\hline & Crimson Seedless & $3.10^{\mathrm{c}}$ & $8.53^{\mathrm{B}}$ & $0.00^{\mathrm{D}}$ & $0.00^{\mathrm{D}}$ & $2.91^{\mathrm{B}}$ \\
\hline & Mean & $4.05^{\mathrm{B}}$ & $9.24^{\mathrm{A}}$ & $0.00^{\mathrm{C}}$ & $0.00^{\mathrm{C}}$ & \\
\hline \multirow{4}{*}{ No. of Leaves Cutting ${ }^{-1}$} & Red Globe & $8.33^{\mathrm{ef}}$ & $4.33^{\mathrm{fg}}$ & $10.66^{\text {bcd }}$ & $10.66^{\text {bcd }}$ & $8.50^{\mathrm{B}}$ \\
\hline & Thompson Seedless & $8.67^{\text {cde }}$ & $3.33^{\mathrm{fg}}$ & $17.00^{\mathrm{a}}$ & $17.00^{\mathrm{a}}$ & $11.50^{\mathrm{A}}$ \\
\hline & Crimson Seedless & $6.00^{\mathrm{ef}}$ & $1.66^{\mathrm{g}}$ & $13.66^{\mathrm{ab}}$ & $12.00^{\mathrm{bc}}$ & $8.33^{\mathrm{B}}$ \\
\hline & Mean & $7.67^{\mathrm{B}}$ & $3.11^{\mathrm{C}}$ & $13.77^{\mathrm{A}}$ & $13.22^{\mathrm{A}}$ & \\
\hline \multirow{4}{*}{ Fresh Weight of Leaves (g) } & Red Globe & $0.76^{\mathrm{bc}}$ & $0.51^{\mathrm{bc}}$ & $2.48^{\mathrm{a}}$ & $2.08^{\mathrm{a}}$ & $1.46^{\mathrm{A}}$ \\
\hline & Thompson Seedless & $0.81^{\mathrm{ab}}$ & $0.55^{\mathrm{ab}}$ & $2.20^{\mathrm{bc}}$ & $1.50^{\mathrm{bc}}$ & $1.26^{\mathrm{A}}$ \\
\hline & Crimson Seedless & $0.93^{\mathrm{a}}$ & $0.69^{\mathrm{a}}$ & $2.14^{\mathrm{ab}}$ & $1.79^{\mathrm{ab}}$ & $1.39^{\mathrm{A}}$ \\
\hline & Mean & $0.83^{\mathrm{C}}$ & $0.58^{\mathrm{C}}$ & $2.27^{\mathrm{A}}$ & $1.79^{\mathrm{B}}$ & \\
\hline \multirow{4}{*}{ Rooting Percentage (\%) } & Red Globe & $46.66^{\mathrm{a}}$ & $16.66^{\mathrm{b}}$ & $70.00^{c}$ & $76.66^{c}$ & $52.50^{\mathrm{C}}$ \\
\hline & Thompson Seedless & $40.00^{\mathrm{b}}$ & $23.33^{\mathrm{a}}$ & $90.00^{\mathrm{a}}$ & $83.33^{\mathrm{b}}$ & $59.16^{\mathrm{A}}$ \\
\hline & Crimson Seedless & $40.00^{\mathrm{b}}$ & $16.66^{\mathrm{b}}$ & $73.33^{\mathrm{b}}$ & $93.33^{\mathrm{a}}$ & $55.83^{\mathrm{B}}$ \\
\hline & Mean & $42.22^{\mathrm{B}}$ & $18.88^{\mathrm{C}}$ & $77.77^{\mathrm{A}}$ & $84.44^{\mathrm{A}}$ & \\
\hline \multirow{4}{*}{ No. of Roots ${ }^{-1}$} & Red Globe & $14.66^{\mathrm{d}}$ & $4.00^{\mathrm{e}}$ & $26.33^{c}$ & $36.00^{\mathrm{b}}$ & $20.25^{\mathrm{B}}$ \\
\hline & Thompson Seedless & $14.00^{\mathrm{d}}$ & $3.66^{\mathrm{e}}$ & $49.00^{\mathrm{a}}$ & $50.00^{\mathrm{a}}$ & $29.16^{\mathrm{a}}$ \\
\hline & Crimson Seedless & $15.00^{\mathrm{d}}$ & $7.33 \mathrm{~d}^{\mathrm{e}}$ & $49.00^{\mathrm{a}}$ & $38.33^{\mathrm{b}}$ & $27.41^{\mathrm{A}}$ \\
\hline & Mean & $14.55^{\mathrm{B}}$ & $5.00^{\mathrm{C}}$ & $41.44^{\mathrm{A}}$ & $41.44^{\mathrm{A}}$ & \\
\hline \multirow{4}{*}{ Fresh Weight of Roots Cutting ${ }^{-1}$} & Red Globe & $0.81^{\mathrm{ef}}$ & $0.45^{\mathrm{f}}$ & $1.62^{\text {cd }}$ & $1.82^{\mathrm{bcd}}$ & $1.17^{\mathrm{B}}$ \\
\hline & Thompson Seedless & $1.56^{\mathrm{cd}}$ & $0.33^{\mathrm{f}}$ & $2.57^{\mathrm{a}}$ & $2.14^{\mathrm{abc}}$ & $1.64^{\mathrm{A}}$ \\
\hline & Crimson Seedless & $1.30^{\mathrm{de}}$ & $0.43^{\mathrm{f}}$ & $2.29^{\mathrm{ab}}$ & $2.44^{\mathrm{ab}}$ & $1.61^{\mathrm{A}}$ \\
\hline & Mean & $1.21^{\mathrm{b}}$ & $0.40^{\mathrm{f}}$ & $2.16^{\mathrm{a}}$ & $2.13^{\mathrm{a}}$ & \\
\hline \multirow{4}{*}{ Chlorophyll Content of Leaves (\%) } & Red Globe & $35.96^{c}$ & $34.00^{\mathrm{a}}$ & $49.72^{\mathrm{c}}$ & $54.84^{\mathrm{c}}$ & $43.63^{\mathrm{A}}$ \\
\hline & Thompson Seedless & $38.30^{\mathrm{a}}$ & $34.00^{\mathrm{a}}$ & $54.88^{\mathrm{a}}$ & $56.25^{\mathrm{b}}$ & $45.85^{\mathrm{A}}$ \\
\hline & Crimson Seedless & $36.73^{b}$ & $33.11^{\mathrm{b}}$ & $52.90^{\mathrm{b}}$ & $57.60^{\mathrm{a}}$ & $45.08^{\mathrm{A}}$ \\
\hline & Mean & $37.00^{\mathrm{c}}$ & $33.70^{\mathrm{c}}$ & $52.50^{\mathrm{B}}$ & $56.23^{\mathrm{A}}$ & \\
\hline \multirow{4}{*}{ Electrolyte Leakage (\%) } & Red Globe & $29.33^{\mathrm{b}}$ & $28.67^{\mathrm{c}}$ & $28.33^{c}$ & $27.67^{c}$ & $28.50^{\mathrm{A}}$ \\
\hline & Thompson Seedless & $30.67^{\mathrm{a}}$ & $31.00^{\mathrm{a}}$ & $30.00^{\mathrm{b}}$ & $27.00^{\mathrm{b}}$ & $29.67^{\mathrm{A}}$ \\
\hline & Crimson Seedless & $28.67^{\mathrm{c}}$ & $30.00^{\mathrm{b}}$ & $32.33^{\mathrm{a}}$ & $30.67^{\mathrm{a}}$ & $30.41^{\mathrm{A}}$ \\
\hline & Mean & $29.56^{\mathrm{bc}}$ & $29.89^{\mathrm{b}}$ & $30.22^{\mathrm{a}}$ & $28.44^{c}$ & \\
\hline
\end{tabular}

Source: Muhammad et al., [32].

CS: Canal Silt, CSFYM: Canal Silt (75\%) + Farmyard Manure (25\%), CSB: Canal Silt (25\%) + Bagasse (75\%), CSBCP: Canal Silt (25\%) + Bagasse $(50 \%)+$ Coco Peat $(25 \%)$. Values are means of three determinations. Means with the same letters (Superscript) are not significantly $(P>0.05)$ different. 
The experiment conducted by Gebreslassie [31] indicated that the highest average number of leaves with values (20) per stem cuttings were counted for hard wood cutting types for media proportion 2TS:1FYM:1FS.

Rashad et al. [32] also reported that Silt media had recorded significantly higher number of leaves $(4.88 \pm 0.53)$. The research done by Ankita [36] identified that the maximum leaves per cutting is obtained in T1(soil) media. The research done by Dhatrika [37] showed that, the highest number of leaves per cutting was recorded in coco peat.

Effect of media on Shoot length of grape: Haile [4] also observed that the stem cuttings rooted in filter cake + sand (50:50v/v) showed significantly larger average shoot length $(26.81$ $\mathrm{cm}$ ) yet statistically not different from those cuttings rooted in agricultural soil + sand $(75: 25 \mathrm{v} / \mathrm{v})$, whereas those cuttings rooted in coco peat $(100 \%)$ gave the shortest $(12.80 \mathrm{~cm})$ average shoot length.

The report of Gebreslassie [31] also shows that longest shoot length $(361 \mathrm{~cm}$ and $350 \mathrm{~cm})$ was recorded for soft wood (SW) cutting and hard wood (HW) cutting grown in rooting media 6TS: 3FYM: 2FS proportion.

Rashad et al. [32] also reported that silt media had recorded significantly higher shoot length $(26.86 \pm 4.63 \mathrm{~cm})$.

The research done by Ankita [36] using 14 treatments: \{T1:soil,T2: coco peat, T3:vermicompost,T4:sand,T5:FYM,T6:soil+sand(1:1),T7:soil+vermicompost(1:1), T8:soil+cocopeat (1:1), T9:soil + FYM(1:1), T10:soil + sand + FYM(1:1:1), T11: soil + sand + vermin compost (1:1:1), T12: soil + sand + cocopeat(1:1:1), T13:sand + FYM + cocopeat (1:1:1), T14: sand +vermin compost + coco peat $(1: 1: 1)\}$ that the maximum leaf length in $\mathrm{T} 4$ (sand) media.

Effect of media on Leaf area (LA) of grape cutting: As the study of Haile [4], Leaf area was significantly $(\mathrm{P} \leq 0.01)$ influenced by rooting media. Cuttings rooted in filter cake + sand (50:50v/v) gave on average of $49.84 \mathrm{~cm}^{2} \mathrm{LA}$, which however was not statistically different from those cuttings rooted in agricultural soil + sand $(75: 25 \mathrm{v} / \mathrm{v})$.

Similar results were reported by Shah et al. [33] and Popescu \& Popescu [20] in that leaf area of rooted cuttings were influenced by the type of rooting media used.

As the report of Gebreslassie [31] the larger leaf area $(5513 \mathrm{~cm})$ was recorded for hard wood cutting grown in 2TS:1FYM:2FS media proportion. Ankita (2012) founded maximum leaf length in sand media and maximum leaf breadth in soil + sand + cocopeat, 1:1:1.

Effect of media on Shoot fresh weight of grape cutting: Haile [4] has also studied the shoot fresh weight of the cutting. In his study he found that the highest shoot fresh weight (25.28 g) was obtained from those cuttings rooted in agricultural soil (100\%), which however was not statistically different from those cuttings rooted in filter cake + sand (50:50 v/v). Sabir et al. [19] and Senegel et al. [30] also noted that shoot fresh weight was significantly determined by the type of rooting media.
Gebreslassie [31] also observed the highest average fresh shoot weight (163g and $160 \mathrm{~g}$ ) was recorded for semi hard wood cutting grown in rooting media 2TS:1FYM:1FS and soft wood cutting grown in rooting media $2 \mathrm{TS}: 1 \mathrm{FYM}: 2 \mathrm{FS}$, respectively.

Rashad et al. [32] reported that the silt media had recorded significantly higher fresh weight of guava cutting $(877.57 \pm 27.26$ $\mathrm{mg}$ ).

Effect of media on shoot thickness of grape cutting: Haile [4] also observed that cuttings rooted in filter cake + sand (50:50v/v) gave thicker $(5.23 \mathrm{~mm})$ shoots yet statistically not different from those cuttings rooted in agricultural soil + sand (75:25 v/v) (Table 3). The findings of Sabir et al. [19] also indicated that highest shoot thickness in one bud grape cuttings rooted in a sand media.

Somkuwar et al. [38] concluded that an increase in cane diameter on basal portion of cuttings (1-4 buds) is because of the accumulation of large amount of reserve food materials.

As the report of Gebreslassie [31] the highest average shoot girth $(2.23 \mathrm{~mm})$ was recorded for semi hard wood cutting type and 6TS: 3FYM:2FS media proportion. In Rashad et al. [32] experiment silt media had recorded significantly higher stem diameter $(5.30 \pm 0.65 \mathrm{~mm})$.

Effect of media on survival percentage of grape cutting: Sharma [39] conducted an experiment on fifteen types of rooting media and maximum success rate of $47 \%$ and survival percentage of $41 \%$ was found in media FYM + soil.

Lakra [40] experimented in Horticulture Nursery, BAU, Kanke on semi hardwood cuttings of passion fruit on 12 types of rooting media $[41,42]$. The maximum shoot length $(20.07 \mathrm{~cm})$ was observed in FYM + soil media. Firoz et al. [43] identified the highest success rate (79.1 and $80.2 \%$ ), with the media containing 50\% sand and $50 \%$ cow dung followed by media containing soil: sand: cow dung (1:1:1).

Singh \& Nair [11] reported the effect of rooting media on cuttings of ornamental plants in red soil, sand and compost (1:2:1), (1:2:2) and (2:1:1). Maximum percent of success was obtained in media red soil: sand: compost $(1: 2: 1)$ that is $100 \%$.

In Rashad et al. [32] experiment silt media had recorded significantly higher survival percentage $(83.33 \pm 16.33 \%)$. Dhatrika [37] also observed that survival percentage of rooted cuttings was higher in coco peat media.

\section{Summary and Conclusion}

Grape vines are very easy to grow from cuttings and generally propagated through hardwood cuttings [44-47]. Adventitious rooting and shoot growth are affected by environmental conditions, exogenous and endogenous biochemical compounds, ontogenetic age of plant material, genotype, characteristics of the cuttings i.e. growth conditions of the stock plant, rooting media and treatment of cuttings.

Types of media have significantly influenced the rooting and vegetative growth of cuttings. Growing media should be considered 
an essential part of the propagation system because rooting competency depends on the type of medium used. Rooting medium directly effect on quality and percentage of rooting [48-52]. Both the biological and Physico-chemical characteristics of a potting medium affect plant and root growth.

Choosing the most suitable growing media for the achievement of a successful plant production is very important. The growth and survival of the grape seedlings in a nursery is greatly affected by the potting medium. As it is a key source of nutrition and provides root system to the cuttings of the plants. Besides, water holding capacity, better aeration, root penetration, presence of organic matter in the growing medium and so many other related factors are greatly influenced by the growing medium [53-57].

From the review we can conclude that growing media significantly influenced the rooting, root and shoot growth performance of grape stem cutting.

The suitability of the rooting medium depends on the species, type of cuttings, growing conditions, season of the year and the cost effectiveness of the medium components. A media which is light, rich, porous, well drained and free from pathogens is considered ideal for growing of grape. A good potting medium must be easy to supply, process and a cheap source.

In general, we can conclude that the mixture of organic and inorganic media is very important for the rooting, root growth and shoot growth of grape propagated by cutting.

\section{Future line of Work}

- Research should focus on the preparation of mixture of media from locally available materials.

- Research output is also premium important on the use of existing commercial mixtures.

- More commercial mixtures should be researched and be available for the end users.

- Integration study of many organic and inorganic growth media is paramount important.

\section{Acknowledgement}

None.

\section{Conflict of Interest}

No conflict of interest.

\section{References}

1. K Kishan Rao (2004) Studies on the propagation of grape rootstocks through hardwood and soft wood cuttings. MSc thesis. Rajendranagar, Hyderabad, pp. 1-97.

2. Mattia F, S Imazio, F Grassi, H Doulati, A Scienza, M Labra (2008) Study of genetic relationships between wild and domesticated grapevine distributed from middleeast regions to European countries. Rendiconti Lincei 19: 223-240.

3. Zecca G, F De Mattia, G Lovicu, M Labra, F Sala, et al. (2009) Wild grapevine: silvestris, hybrids or cultivars that escaped from vineyards. Molecular evidence in Sardinia. Plant Biology. German Botanical Society and the Royal Botanical Society of the Netherlands, pp. 1-6.
4. Haile Abebe (2017) Effect of cane length and rooting media on rooting and shoot growth of grape (vitis vinifera l.) stem cuttings at raya valley, northern Ethiopia. MSc thesis. Hawassa University College of Agriculture.

5. Muhammad Farooq, Kaleem Kakar, Moses Kwaku Golly, Naila Ilyas, Bakhshah Zib, et al. (2018) Comparative Effect of Potting Media on Sprouting and Seedling Growth of Grape Cuttings. International Journal of Environmental \& Agriculture Research (IJOEAR) 4: 2454-1850.

6. Food and Agriculture organization of the United Nations (FAOSTAT) (2017) Ethiopia: Grapes, production quantity (tons).

7. Verdegaal PS (2009) Vineyard propagation. Farm Advisor. San Joaquin Country, pp. 1.

8. Patil VN, PS Chauhan, RS Shivankar, SH Vilhekar, VS Waghmare (2001) Effect of plant growth regulators on survival and vegetative growth of grapevine cuttings. Agricultural Science Digest 21(2): 97-99.

9. Somkuwar RG, DD Bondage, MS Surange, SD Ramteke (2011) Rooting behavior, polyphenol oxidase activity, and biochemical changes in grape rootstocks at different growth stages. Turk Journal of Agriculture 35: 281-287.

10. Alikhani L, K Ansari, M Jamnezhad, Z Tabatabaie (2011) The effect of different mediums and cuttings on growth and rooting of pomegranate cuttings. Iranian Journal of Plant Physiology 1(3): 199-203.

11. Singh DR, Nair SA (2003) Standardization of rooting media for cuttings of certain house plants; Journal of Ornamental Horticulture 6(1): 78-79.

12. Smart D, E Schwass, A Lakso, L Morano (2006) Grapevine rooting patterns: A comprehensive analysis and review. American Journal of Enology and Viticulture 57(1): 89-104.

13. Waite H, M Whitelaw Weckert, P Torley (2015) Grapevine propagation. Principles and methods for the production of high-quality grapevine planting material. New Zealand Journal of Crop and Horticultural Science 43(2): 144-161.

14. Wei June Lu (1958) The effects of re1ant hormones, rooting media, and intermittent mist on the rooting and transplanting of herbaceous, evergreen, and hardwood cuttings. Thesis. Montana State University.

15. Keeley K, JE Preece, BH Taylor (2003) Increased Rooting of 'Norton' grape cuttings using Auxin and Gibberellin biosynthesis inhibitors. Hort Science 38(2): 281-283.

16. Karakurt H, R Aslantas, G Ozkan, M Guleryuz (2009) Effects of indol3-butyric acid (IBA), plant growth promoting rhizobacteria (PGPR) and carbohydrates on rooting of hardwood cutting of MM106 Apple rootstock. African Journal of Agricultural Research 4(2): 060-064.

17. Galavi M, MA Karimian, SR Mousavi (2013) Effects of different auxin (iba) concentrations and planting beds on rooting grape cuttings (Vitis vinifera). Annual Review and Research in Biology 3(4): 517-523.

18. Dvin SR, EG. Moghadam, M Kiani (2011) Rooting response of hardwood cuttings of MM111 Apple clonal rootstock to Indolebutyric acid and rooting media. Asian Journal of Applied Sciences 4(4): 453-458.

19. Sabir A, Z Kara, F Küçükbasmact, NK Yücel (2004) Effects of different rooting media and auxin treatments on the rooting ability of Rupestris $\mathrm{du}$ Lot (Vitis rupestris) rootstock cuttings. Food, Agriculture and Environment 2(2): 307-309.

20. Popescu GH, M Popescu (2015) Effects of different potting growing media for Petunia grandiflora and Nicotiana alata Link \& Otto on photosynthetic capacity, leaf area, and flowering potential. Chilean Journal of Agricultural Research 75(1): 21-26.

21. Brightwell WT (1998) Propagation of the rabbiteye blueberry. Proc Americ Soc Hort Sci, pp. 52-289.

22. Ishizaki A (1991) Rooting and growth of cuttings of doronoki (Populus maximowiczii) in relation to cutting media. Jour Japanese Forest Soc 33(10): 325.

23. Hartmann HT, Kester DE, Davies FT, Geneve RL (1997) Plant propagation principles and practices. Prentice hall ENG. Cliffs, New Jersey, pp. 276391. 
24. Ibrahim Hakeem Kontoh (2008) Propagation of voacanga africana cuttings for the protection of water bodies in the transitional zone of ghana. msc thesis submitted to faculty of renewable natural resources, college of agriculture and natural resources, Ghana.

25. Tsipouridis C, T Thomidis, Z Michailides (2005) Factors influencing the rooting of peach GF677 (peach x almond hybrid) hardwood cuttings in a growth chamber. New Zealand Journal of Crop and Horticultural Science 33(2): 93-98.

26. Ferrer M, Guarinoni A, Camussi G (1991) Effect of the rooting media and date of cuttings extraction on the quantity and quality of rooting in the grape rootstock SO4 (Vitis riparia x Vitis berlandieri) and determination of a critical phenological stage. Boletin-de-Investigacion-FacultaddeAgronomia, Universidad-de-la-Republica 31: 1-11.

27. Kawecki Z, Kozlowski WM (1995) Effect of different organic substrates on rooting of one-bud hardwood grapevine cuttings. Acta Academiae Agriculturae Technicae Olstenensis 60: 99-106.

28. Cyrillo FLL, Kimura A, Roberto SR, Teixeira LAJ, Pereira FM (1999) Propagation of grapevine rootstocks by semi hardwood cuttings in two substrates, in a mist chamber. Revista Brasileira-de-Fruiticultura 21(3): 266-268.

29. Song YG, Lu WP, Wang J, Shen YJ, Wu ZS, et al. (2001) Study on promoting the rooting ability of hardwood cuttings of Amurien grape varieties. China Fruits 1: 4-7.

30. Sengel E, B Isci, A Ahmet (2012) Effects of different culture media on rooting in grafted grapevine. Ege Üniviversity Ziraat Fakültesi Derg 49(2): 143-148.

31. Gebreslassie Hailu Gidey (2014) Influence of rooting media, cutting types and watering frequency on nursery performance of long pepper (piper cappense) at jimma. MSc thesis submitted to the school of graduate studies jimma university college of agriculture and veterinary medicine.

32. Qadri R, M Azam, SB Khan, I Khan, I Ul Haq, et al. (2018) Growth performance of guava cutting under different growing media and plant cutting taking height. Bulg. J Agric Sci 24(2): 236-243.

33. Shah M, AM Khattak, N Amin (2006) Effect of different growing media on the rooting of Ficus binnendijkii 'Amstel queen' cuttings. Journal of Agricultural and Biological Science 1(3): 15-17.

34. Hong SY, Kim SD, Lee YS, Choi SY (2002) Selection of transplanting soil for acclimatization of in vitro cultured grapevine plantlets. Korean Journal of Horticultural Science Technology 20(1): 38-41.

35. Singh K, S Raghava, R Misra (2002) Effect of media on rooting of carnatin cuttings. Journal of Ornamental Horticulture (India).

36. Ankita Srivastava (2012) Effect of media on rooting of semihardwood cutting of peach (prunus persica l.) thesis submitted to the birsa agricultural university, kanke, ranchi.

37. Dhatrika Rani T, Srihari D, Dorajeerao AVD, Subbaramamma P (2018) Effect of rooting media and IBA treatments on success of propagation through terminal cuttings in guava (Psidium guajava L.) cv. Taiwan Pink. Journal of Pharmacognosy and Phytochemistry 7(5): 2953-2959.

38. Somkuwar RG, M Bhange, J Sharma, AK Upadhyay, I Khan (2017) Interaction of biochemical and nutritional status of nodal sections with rooting success in grape rootstocks. Journal of environmental biology 38: $115-121$.

39. Sharma Y (1993) Studies on the effect of different rooting media on rooting of hard wood,semihard wood and soft wood cutting of mulberry (Morusnigra L.), M.Sc. Ag (Horti) Thesis, BAU.

40. Lakra SK (2004) Effect of media on rooting of cutting of Passion fruit (Passiflora edulis) M.Sc. (Ag.) Hort Thesis, BAU.
41. Bodor P, L Baranyai, M Ladányi, B Bálo, AE Strever, et al. (2013) Stability of ampelometric characteristics of Vitis vinifera L. cv. 'Syrah' and 'Sauvignon blanc' leaves: Impact of within-vineyard variability and pruning method/bud load. South African Journal of Enology and Viticulture 34(1):129-137.

42. Fageria NK, A Moreira A (2011) The role of mineral nutrition on root growth of crop plants. In Donald L Sparks (edt) Advances in Agronomy, Academic Press, Burlington 110: 251-331.

43. Firoz ZA, Husaain MM, Choudhary AK, Choudhary MMU (1997) Effect of soil media and type of cuttings in cherry propagation. Annals of Bangladesh Agriculture 7(1): 69-72.

44. Gambetta GA, CM Manuck, ST Drucker, T Shaghasi, K Fort, et al. (2012) The relationship between root hydraulics and scion vigour across Vitis rootstocks: what role do root aquaporins play. Journal of Experimental Botany 63(18): 6445-6455.

45. Gökbayrak Z, A Dardeniz, A Arıkan, U Kaplan (2010) Best duration for submersion of grapevine cuttings of rootstock 41B in water to increase root formation. Journal of Food, Agriculture and Environment 8 (3\&4): 607-609.

46. Kukuva AA (1989) Innovation in fijoa propagation from cuttings and the growth characteristics of the cuttings. Sub Tropicheskie Kulturz 4: 2124.

47. Lal SD, Danu SN (1985) Rooting carnation cuttings as influenced by different rooting media. Progressive Horticulture 17(2): 145-147.

48. Lanyon DM, A Cass, D Hansen (2004) The effect of soil properties on vine performance. CSIRO Land and Water Technical Report 34(4): 1-54.

49. Lebon E, A Pellegrino, G Louarn, J Lecoeur (2006) Branch development controls leaf area dynamics in grapevine (Vitis vinifera) growing in drying soil. Annals of Botany 98: 175-185.

50. Lobato A, Carrasco J, Ruiz R, Agvirre A (2001) Rockwool and chitosan as an alternative technology for grape propagation in containers. Revista Fruiticola 22(3): 77-82.

51. Quezada C, MA Soriano, J Díaz, R Merino, A Chandía, et al. (2014) Influence of soil physical properties on grapevine yield and maturity components in an ultic palexeralf soils, Central-Southern, Chile. Open Journal of Soil Science 4(4):127-135.

52. Sadhu MK (1986) Vegetative propagation practices. In: Propagation of tropical and sub-tropical horticultural crops (ed Bose TK, Mitra SK and Sadhu MK). Naya Prokash, Kolkata, pp. 36-38.

53. Shelton LL, Moore JN (1981) High bush berry propagation under Southern US climatic conditions. Hort Science 16(3): 320-321.

54. Serra I, A Strever, PA Myburgh, A Deloire (2014) Review: the interaction between rootstocks and cultivars (Vitis vinifera L.) to enhance drought tolerance in grapevine. Australian Journal of Grape and Wine Research 20: $1-14$.

55. Swanepoel JJ, JM Southey (1989) The influence of rootstock on the rooting pattern of the grapevine. South African Journal of Enology and Viticulture 10(1): 23-28.

56. Wan Y, HR Schwaninger, AM Baldo, JA Labate, G Zhong, et al. (2013) A phylogenetic analysis of the grape genus (Vitis L.) reveals broad reticulation and concurrent diversification during neogene and quaternary climate change. BioMed Central Evolutionary Biology 13 (141): 1-20.

57. Zhuang FY, Wu Z, Li SJ (2001) Rapid propagation of Vitis vinifera plantlets on non-organic medium. Plant Physiology Communications 37(4): 298-299. 